\title{
Hereditary Determination of the Leukosis Virus Resistance of Cattle in Kuzbass
}

\author{
Natalya A. CHALOVA
}

Ph.D. (in Agricultural Sciences)

Associate Professor

Department of Breeding and Genetics in Animal Husbandry

Zootechnics Faculty

Kuzbass State Agricultural Academy

5, Markovtsev Str., Kemerovo, 650056, Russian Federation

$$
\begin{aligned}
& \text { 7(3842)604566 } \\
& \text { natchal@mail.ru }
\end{aligned}
$$

\section{Vladimir A. PLESHKOV}

Ph.D. (in Agricultural Sciences)

Associate Professor

Department of Selection and Genetics in Animal Husbandry

Zootechnics Faculty

Kuzbass State Agricultural Academy

5, Markovtsev Str., Kemerovo, 650056, Russian Federation

$7(3842) 604566$

6110699@mail.ru

\begin{abstract}
The purpose of the current work is to study the hereditary determination of the resistance of the black-and-white Holsteinized cattle of Kuzbass to bovine leucosis virus. The studies were carried out on the basis of the Research Laboratory "of Biochemical, Molecular Genetic Studies and Farm Animal Breeding" of Kuzbass State Agricultural Academy. Cattle genotyping according to BoLA DRB3 was carried out on blood samples by polymerase chain reaction (PCR) followed by analysis of restriction fragment length polymorphism (RFLP). The studied population of cattle demonstrates a predominant distribution of alleles associated with susceptibility to leucosis and neutral disease $88.5 \%$, with sensitivity alleles prevailing $-44.9 \%$ versus to $43.6 \%$ neutral. The frequency of the desired alleles associated with resistance to leucosis disease is only $11.5 \%$. The frequency of genotype resistance to Bovine leucosis virus is $18.18 \%$ in general, and the genotypes that do not carry resistance alleles and carry susceptibility alleles are $62.04 \%$.
\end{abstract}

Keywords: cattle; leucosis; BoLa-DRB3 gene. 


\section{Introduction}

Cattle leucosis is one of the main diseases common in livestock enterprises in most regions of Russia (Burdov et al., 2017, Kozyreva, Gulyukin, 2017).

Modern DNA technologies, widely used in animal husbandry in the developed countries of the world, contribute to the development of genomic breeding and directed selection-breeding work with farm animals. Genetic examination of animals is currently an important element of breeding process in the development and breeding of highly productive livestock (Christian et al., 2010; Kobayashi et al., 2014; Oltenacu, Broom, 2010; Sashital et al., 2011; Torikai et al., 2012). Molecular genetic analysis of the genome to determine the presence or absence of economically valuable traits in the studied animal allows its assessment both in terms of productivity and resistance to diseases (Groenen et al., 1990; Jiang et al., 2013; Polanski, Anderson, 2007; Van Eijk et al., 1992).

Numerous studies conducted on a large number of animals in several countries of the world have made it possible to establish a more frequent manifestation of leucosis in the offspring of the same bulls, which may indicate a genetic component in the spread of the disease of cattle leucosis virus. Researchers note the existing relationship between certain alleles of the BOLA-DRB-3 gene of the main histocompatibility complex and susceptibility to leucosis (Sulimova et al., 1995; Groenen et al., 1990; Xu et al., 1993; Zanotti et al., 1996). It was also established that the susceptibility of an animal, as a rule, is associated with its increased productivity - in highly productive animals, alleles of sensitivity to cattle leucosis virus of cattle prevail (Gendjieva et al., 2012; Gladyr et al., 2010; Gulyukin et al., 2016; Kozyreva, Gulyukin, 2017).

The BoLa-DRB-3 gene of Bos taurus is characterized by high allelic polymorphism. To date, more than 119 of its allelic variants are known. Some alleles of this gene are associated with resistance to leucosis disease, others with susceptibility to this disease, while others have no associative ties with animal leucosis disease (neutral alleles).

Numerous studies have shown the association of the alleles 0902, 2701, 2702, 2703, 2704, 2705, 2706, and 0701 with the resistance of animals to leucosis disease and the relationship of the alleles 1201, 1501, 1502, 1101, 0101, and 0102 with susceptibility to this disease (Gil'manov, 2017).

The purpose of our research is to study the hereditary determination of the resistance of the blackmotley Holsteinized cattle in Kuzbass to bovine leucosis virus. 


\section{Methods}

The object of research is cows of black-motley breed of the Kemerovo region.

The material for studying the polymorphism of the BoLA-DRB-3 gene was the blood of animals (cows) of black-motley breed. For research, blood of 200 animals was taken. Alleles of the BoLADRB-3 gene were identified in 187 animals.

The studies were carried out on the basis of the research laboratory "of Biochemical, MolecularGenetic Studies and Farm Animal Breeding" of the Federal State Budgetary Educational Institution of Higher Education Kuzbass State Agricultural Academy in 2019.

Cattle were genotyped according to the BoLA-DRB-3 gene by blood samples using the polymerase chain reaction (PCR) followed by analysis of restriction fragment length polymorphism (RFLP) in the laboratory of LLC "My Gene" (Moscow).

The determination of allele frequencies was carried out taking into account the number of homozygotes and heterozygotes according to the corresponding allele according to the formula:

$P=\frac{2 \cdot N_{1}+N_{2}}{2 \cdot n}$

where $N_{l}$ and $N_{2}$ - number of homozygotes and heterozygotes for the studied allele, respectively; $n$ - number of samples.

The statistical error for the allele frequency was determined by the formula:

$M_{p}=\sqrt{\frac{P_{i} \cdot\left(1-P_{i}\right)}{2 \cdot N}}$,

where $P_{i}$ - frequency of the allele;

$\mathrm{N}$ - number of animals.

For biometric data analysis, the MS Excel application (Microsoft Office) was used.

\section{Results}

As a result of the animal study on the carriage of alleles of the BoLa-DRB-3 gene, 55 allelic variants of the studied gene were identified.

The presence of a large number of allelic variants is due to the breed formation and is consistent with the data of many authors (Gendjieva et al., 2012; Gil'manov, 2017; Kovalyuk et al., 2012; Kozlov, 2016; Sulimova et al., 1995; Xu et al., 1993; Zanotti et al., 1996). 
Among the alleles associated with resistance to leucosis, 4 variants were identified - 0701, 0902, 2701 and 2703 (in 2018, there were fewer variations revealed - 3 alleles - 0701, 0902, 2703). Among the alleles associated with susceptibility to leucosis, there are 4 variants - 0101, 1101, 1201 and 1501 (in 2018 there were the same 4 alleles: 0101, 1101, 1201 and 1501). The remaining specific alleles are neutral, that is, the relationship between their presence in the animal's genotype and resistance to or susceptibility to leukemia is not proven - 0103, 0201, 0401, 0501, 0601, 0801, 1001, 1002, 1103, 1202, 1301, 1302, 1504, 1505, 1601, 1602, 1701, 1801, 1901, 1902, 2002, 2101, 2201, 2601, 2707, 2801, 2802, 3101, 3103, 3501, 3601, 3801, 4001, 4401, 5101, 5701, 5702, 5801, 6101, 6401, 6601, 6701, 6801, 7001, 14011, 20012, 46011.

The frequency of different allele variant occurrence is presented in Tables 1-3.

Table 1. The frequency of occurrence in the studied population of alleles the BoLa-DRB-3 gene associated with leucosis resistance

\begin{tabular}{cccc} 
Alleles & $\begin{array}{c}\text { Number of } \\
\text { carriers }\end{array}$ & Number of alleles & $\begin{array}{c}\text { Occurrence } \\
\text { frequency }\end{array}$ \\
\hline 0701 & 17 & 17 & $0.04545 \pm 0.010770$ \\
\hline 0902 & 15 & 21 & $0.05615 \pm 0.011904$ \\
\hline 2701 & 1 & 1 & $0.00267 \pm 0.002665$ \\
\hline 2703 & 4 & 4 & $0.01070 \pm 0.005320$ \\
\hline Total & 37 & 43 & $0.11497 \pm 0.016492$
\end{tabular}

In the studied population, the frequency of occurrence of leucosis virus-resistant alleles was $11.5 \%$. The most common allele is $0902-5.62 \%$. It should be noted that only this allele from the leucosis resistance group is found in the animal genotype of cattle bred in the Kuzbass in a homozygous state.

Table 2. The frequency of occurrence in the studied population of alleles of the BoLa-DRB-3 gene associated with susceptibility to leucosis

\begin{tabular}{cccc} 
Alleles & $\begin{array}{c}\text { Number of } \\
\text { carriers }\end{array}$ & Number of alleles & $\begin{array}{c}\text { Occurrence } \\
\text { frequency }\end{array}$ \\
\hline 0101 & 26 & 26 & $0.06952 \pm 0.013149$ \\
\hline 1101 & 58 & 59 & $0.15775 \pm 0.018847$ \\
\hline 1201 & 25 & 25 & $0.06684 \pm 0.012911$ \\
\hline 1501 & 56 & 58 & $0.15508 \pm 0.018716$ \\
\hline Total & 165 & 168 & $0.44919 \pm 0.025720$
\end{tabular}

The frequency of alleles associated with the sensitivity of cattle to the bovine leucosis virus in the study population was $44.9 \%$. All four identified leucosis sensitivity alleles have a prevalence rate of more than 5\%. The most common alleles are $1101-15.8 \%$ and $1501-15.5 \%$ - both in the heterozygous and in the homozygous state. 
Table 3. The frequency of occurrence in the studied population of alleles of the BoLa-DRB-3 gene neutral with respect to the leucosis virus

\begin{tabular}{|c|c|c|c|}
\hline Alleles & $\begin{array}{l}\text { Number of } \\
\text { carriers }\end{array}$ & Number of alleles & $\begin{array}{l}\text { Occurrence } \\
\text { frequency }\end{array}$ \\
\hline 0103 & 1 & 1 & $0.00267 \pm 0.002665$ \\
\hline 0201 & 2 & 2 & $0.00535+0.003768$ \\
\hline 0401 & 1 & 1 & $0.00267 \pm 0.002665$ \\
\hline 0501 & 1 & 1 & $0.00267 \pm 0.002665$ \\
\hline 0601 & 28 & 29 & $0.07754+0.013828$ \\
\hline 0801 & 6 & 6 & $0.01604 \pm 0.006488$ \\
\hline 1001 & 13 & 13 & $0.03476 \pm 0.009471$ \\
\hline 1002 & 3 & 3 & $0.00802+0.004604$ \\
\hline 1103 & 3 & 3 & $0.00802 \pm 0.004604$ \\
\hline 1202 & 1 & 1 & $0.00267 \pm 0.002665$ \\
\hline 1301 & 1 & 1 & $0.00267 \pm 0.002665$ \\
\hline 1302 & 2 & 2 & $0.00535+0.003768$ \\
\hline 1504 & 4 & 4 & $0.01070 \pm 0.005320$ \\
\hline 1505 & 1 & 1 & $0.00267 \pm 0.002665$ \\
\hline 1601 & 2 & 2 & $0.00535+0.003768$ \\
\hline 1602 & 2 & 2 & $0.00535 \pm 0.003768$ \\
\hline 1701 & 1 & 1 & $0.00267 \pm 0.002665$ \\
\hline 1801 & 27 & 27 & $0.07219 \pm 0.013379$ \\
\hline 1901 & 2 & 2 & $0.00535 \pm 0.003768$ \\
\hline 1902 & 3 & 3 & $0.00802 \pm 0.004604$ \\
\hline 2002 & 1 & 1 & $0.00267 \pm 0.002665$ \\
\hline 2101 & 2 & 2 & $0.00535 \pm 0.003768$ \\
\hline 2201 & 1 & 1 & $0.00267 \pm 0.002665$ \\
\hline 2601 & 4 & 4 & $0.01070+0.005320$ \\
\hline 2707 & 1 & 1 & $0.00267 \pm 0.002665$ \\
\hline 2801 & 1 & 1 & $0.00267 \pm 0.002665$ \\
\hline 2802 & 1 & 1 & $0.00267+0.002665$ \\
\hline 3101 & 3 & 3 & $0.00802 \pm 0.004604$ \\
\hline 3103 & 3 & 3 & $0.00802 \pm 0.004604$ \\
\hline 3501 & 1 & 1 & $0.00267+0.002665$ \\
\hline 3601 & 2 & 2 & $0.00535 \pm 0.003768$ \\
\hline 3801 & 1 & 1 & $0.00267 \pm 0.002665$ \\
\hline 4001 & 1 & 1 & $0.00267+0.002665$ \\
\hline 4401 & 1 & 1 & $0.00267 \pm 0.002665$ \\
\hline 5101 & 2 & 2 & $0.00535 \pm 0.003768$ \\
\hline 5701 & 1 & 1 & $0.00267 \pm 0.002665$ \\
\hline 5702 & 2 & 2 & $0.00535 \pm 0.003768$ \\
\hline 5801 & 1 & 1 & $0.00267 \pm 0.002665$ \\
\hline 6101 & 1 & 1 & $0.00267 \pm 0.002665$ \\
\hline 6401 & 1 & 1 & $0.00267 \pm 0.002665$ \\
\hline 6601 & 1 & 1 & $0.00267 \pm 0.002665$ \\
\hline 6701 & 3 & 3 & $0.00802 \pm 0.004604$ \\
\hline 6801 & 2 & 2 & $0.00535 \pm 0.003768$ \\
\hline 7001 & 3 & 3 & $0.00802 \pm 0.004604$ \\
\hline 14011 & 14 & 14 & $0.03743+0.009813$ \\
\hline 20012 & 1 & 1 & $0.00267 \pm 0.002665$ \\
\hline 46011 & 3 & 3 & $0.00802 \pm 0.004604$ \\
\hline Total & 162 & 163 & $0.43576+0.025640$ \\
\hline
\end{tabular}


IV International Scientific and Practical Conference "Modern S\&T Equipments and Problems in Agriculture"

The greatest polymorphism was observed in neutral alleles of the BoLa-DRB-3 gene - 47 variants. In general, their frequency was $43.6 \%$. The most common alleles are $0601-7.8 \%$ and $1801-7.2 \%$. The remaining options make up less than $5 \%$ of the frequency of each allele.

In general, for the studied group of cattle, the total frequency of neutral alleles was $43.6 \%$, alleles associated with resistance to leucosis disease $-11.5 \%$, and alleles associated with susceptibility to leucosis disease $-44.9 \%$ (Figure 1).

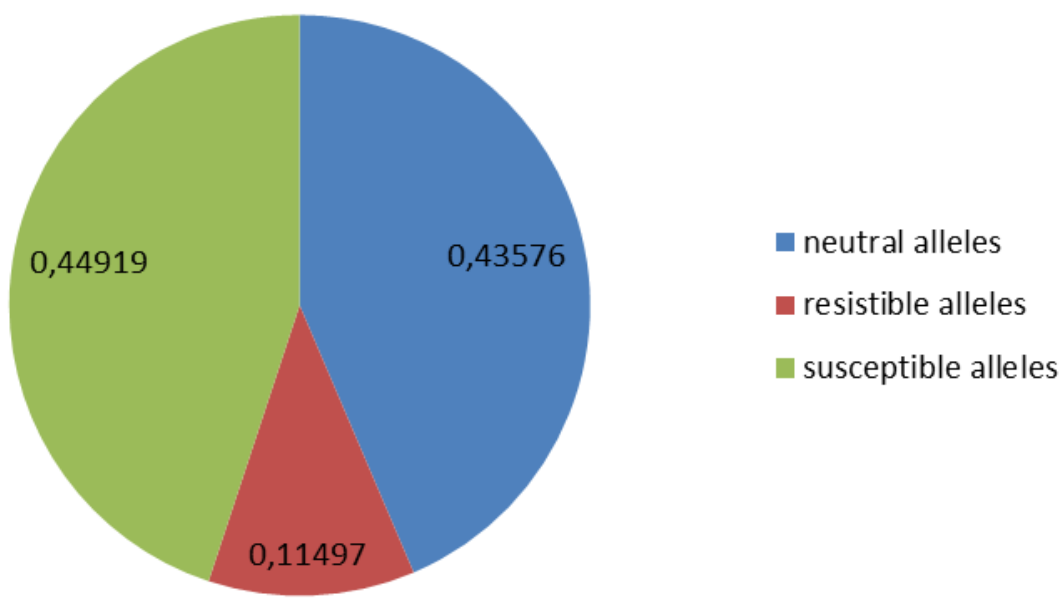

Figure 1. Frequency distribution of alleles

7 alleles of the BoLa-DRB3 gene were detected with a frequency of occurrence of more than $5 \%$. Of these, two neutral alleles - $0601-7.8 \%$ and $1801-7.2 \%$, one allele associated with leucosis resistance - $0902-5.6 \%$, and the remaining 4 alleles $(0101,1101,1201$ and 1501) are associated with sensitivity to leucosis - their frequency ranges from 6.7 to $15.8 \%$.

Thus, in the study group, there is a predominant distribution of alleles associated with susceptibility to leucosis and neutral ones - $88.5 \%$, with sensitivity alleles prevailing - $44.9 \%$ versus $43.6 \%$ neutral. The frequency of the desired alleles associated with resistance to leucosis disease is only $11.5 \%$.

The studied group of cattle of black-motley breed is characterized by a wide variety of genotypes a total of 84 variants of various combinations of alleles were identified. This variation is explained by the fact that gene polymorphism is maintained at the population level. Moreover, each individual can carry only a pair of alleles of one gene. And since the set of alleles in a population can be very wide, their random combination leads to a huge number of genotypes. 
Out of 84 genotypes, 62 were presented in a single copy and 9 had two animals. The prevailing genotypes are difficult to identify. With a frequency of more than 5\%, genotypes $1101 / 1801(\mathrm{~S} / \mathrm{N})$ $10.70 \%, 0101 / 1501(\mathrm{~S} / \mathrm{S})-9.63 \% ; 1101 / 0601(\mathrm{~S} / \mathrm{N})-6.95 \%$ and 1101/1501 (S/S) - 5.35\%.

Thus, genotypes prevailing in the herd, bearing in their composition an allele of sensitivity to leucosis.

When studying a population for resistance or susceptibility to bovine leucosis virus, special attention must be paid to the distribution of genotypes.

Based on the functional significance of the alleles, all available genotypes in the studied population were divided into groups: susceptible/susceptible (S/S), resistant/resistant (R/R), neutral/neutral $(\mathrm{N} / \mathrm{N})$, resistant/neutral $(\mathrm{R} / \mathrm{H})$, susceptible/neutral $(\mathrm{S} / \mathrm{N})$ and resistant/susceptible (R/S). The genotypes of the first three groups should theoretically provide resistance to cattle leucosis.

Figure 2 shows the frequency distribution of the groups of animal genotypes of the black-motley breed, bred in the Kuzbass.

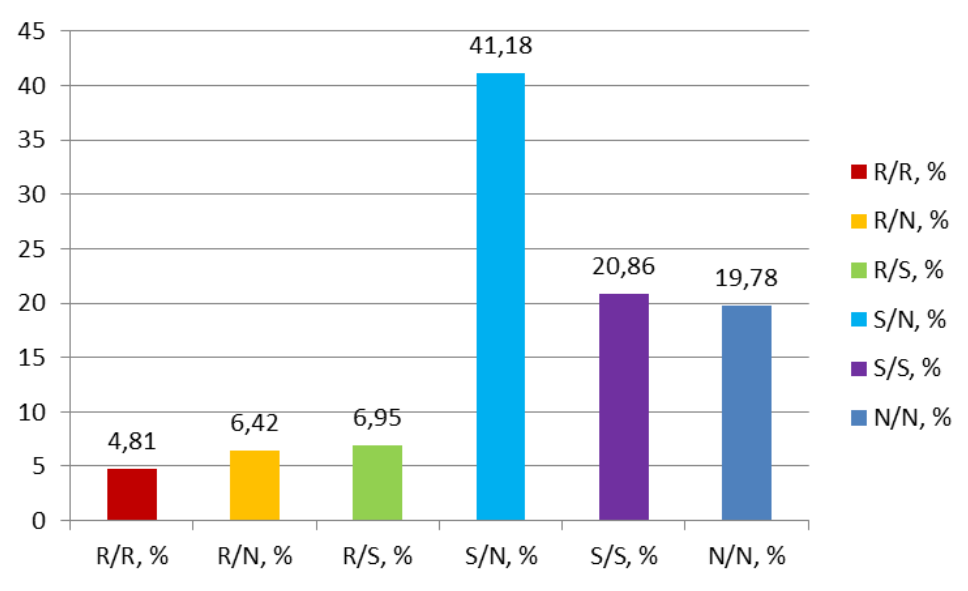

\section{Figure 2. Frequency of genotypes by functional groups of alleles, \%}

The studied population of black and white cows showed the frequency of genotypes of resistance to Bovine leucosis virus of $18.18 \%$ in general, and the genotypes not bearing resistance alleles and susceptibility alleles of $62.04 \%$, i.e. 3.4 times higher.

The combination of the allele, which determines the sensitivity to leucosis, and the neutral allele, $41.18 \%$, as well as the combination of two alleles, which determine the susceptibility to the leucosis virus, $20.86 \%$ and the neutral ones, $19.78 \%$, are most often found within the framework of one genotype.

Thus, the BoLA-DRB-3 genotypes associated with susceptibility to cattle leucosis predominate in the studied population of black-motley cattle of the Kemerovo region. 


\section{Discussion}

Currently, for the reproduction of a cattle herd, the sperm of bulls is widely used, evaluated by a set of characters, including a molecular genetic marker, and, in particular, on the BoLA-DRB-3 gene polymorphism. But, as it is known, hereditary information is equally transmitted to descendants from both the father and the mother. Therefore, the assessment of the breeding stock of cattle by marker genes, including the gene for resistance to leucosis, is of great importance for successful breeding work. By competent assessment, selection and selection of animals, one can not only increase the level of productive qualities of animals, but also improve the herd.

The analysis of the obtained data made it possible to evaluate the polymorphism of the BoLA-DRB3 gene of black-motley cattle breed in the Kemerovo region. In general, the studied population is characterized by a high level of polymorphism of this gene.

The Kuzbass cattle population has a rather high level of sensitivity alleles and genotypes, therefore, it has low genetic resistance to leucosis virus.

The results will allow more efficient breeding of cattle of black-motley breed, bred in the Kemerovo region.

\section{Conclusion}

1. In the sample consisting of 187 cows of black-motley breed, bred in the conditions of the Kemerovo region, there were identified 55 allelic variants.

2. The total frequency of neutral alleles in the studied sample was $43.6 \%$, alleles of resistance to leucosis disease $-11.5 \%$, and alleles of susceptibility to leucosis virus $-44.9 \%$.

3. The studied livestock of black-motley cattle is characterized by a high level of polymorphism of genotypes - a total of 84 variants of various combinations of alleles were identified. With a frequency of more than 5\%, only genotypes 1101/1801 (10.70\%), 0101/1501 (9.63\%), 1101/0601 (6.95\%) and 1101/1501 (5.35\%) are represented.

4. The frequency of genotypes that determine resistance to leucosis is $18.18 \%$, and the genotypes associated with susceptibility and not bearing resistance alleles are $62.04 \%$.

5. Within the framework of one genotype, the most common combination of the leucosis susceptibility allele and the neutral allele is $41.18 \%$, as well as the combination of two alleles that make the animal susceptible to leucosis - $20.86 \%$ and two neutral alleles $19.78 \%$. 


\section{Acknowledgments}

The authors are grateful for the help in organizing the selection of biological material Smolovskaya, head of the Research Laboratory "of Biochemical, Molecular Genetic Research and Farm Animal Breeding” and Mironov A.N., post-graduate student of Kuzbass State Agricultural Academy.

\section{References}

Burdov, G.N., Kotelnikov, N.N., Yavkin, S.G., et al. (2017). Epizootic situation of leukemia in cattle in the Udmurd Republic in 2011-2015. Veterinary medicine, 8, 4-8.

Christian, M., Cermak, T., Doyle, E.L., Schmidt, C., Zhang, F., Hummel, A., Bogdanove, A.J., Voytas, D.F. (2010). Targeting DNA double-strand breaks with TAL effector nucleases. Genetics, 186(2), 757-761. DOI: 10.1534/genetics.110.120717

Gendjieva, O.B., Kornikova, A.S., Moiseykina, L.G. (2012). The method of cattle selection for resistance and susceptibility to leukemia. RF Patent 2012104128 A01K 67/00.

Gil'manov, K.K. (2017). Variety of alleles of the marker gene BOLA-DRB3. Proceedings of the International scientific-practical conference "Science today: global challenges and development mechanisms”, 61-62). Vologda: Scientific Center Dispute.

Gladyr, E.A., Zinovieva, N.A., Bykova, A.S., Ernst, L.K. (2010). A method for the diagnosis of resistance of cattle to leukemia virus. RF Patent 2428485 C12Q 1/68.

Groenen, M.A.M., et al. (1990). The nucleotide sequence of bovine MHC class II DQB and DRB genes. Immunogenetics, 31, 37. DOI: 10.1007/BF00702487

Gulyukin, M.I., Kozyreva, N.G., Ivanova, L.A., et al. (2016). Genetic polymorphism of the cattle leukemia virus in the territory of the Russian Federation. Russian Agricultural Science, 5, 56-59.

Jiang, W., Bikard, D., Cox, D., Zhang, F., Marraffini, L.A. (2013). RNA-guided editing of bacterial genomes using CRISPR-Cas systems. Nature Biotechnology, 31(3), 233-239.

Kobayashi, S., Hidano, A., Tsutsui, T., Yamamoto, T., Hayama, Y., Nishida, T., et al. (2014). Analysis of risk factors associated with bovine leukemia virus seropositivity within dairy and beef breeding farms in Japan: A nationwide survey. Research in Veterinary Science, 96, $47-53$. 
Kovalyuk, N.V., Satsuk, V.F., Volchenko, A.E. (2012). Variability of the BoLA-DRB3 gene in cattle of the dairy direction of productivity and its influence on viability parameters. Russian Journal of Genetics, 48(8), 819-822. DOI: 10.1134/S1022795412070083

Kozlov, A.L. (2016). Polymorphism of the BoLA-DRB3 gene as a marker for assessing genetic diversity and resistance to leukemia virus in dairy cattle of the Bryansk region. Thesis, Bryansk State University, Bryansk.

Kozyreva, N.G., Gulyukin, M.I. (2017). The spread of leukemia in cattle and genetic variants of the pathogen on the territory of livestock farms of the Central Federal District of the Russian Federation. Veterinary Medicine of the Kuban, 6, 4-9.

Oltenacu, P.A., Broom, D.M. (2010). The impact of genetic selection for increased milk yield on the welfare of dairy cows. Animal Welfare, 19(11), 39-49.

Polanski, M., Anderson, N.L. (2007). A list of candidate cancer biomarkers for targeted proteomics. Biomarker Insights, 1, 1-48. DOI: 10.1177/117727190600100001

Sashital, D.G., Jinek, M., Doudna, J.A. (2011). An RNA-induced conformational change required for CRISPR RNA cleavage by the endoribonuclease Cse3. Nature Structural and Molecular Biology, 18(6), 680-687. DOI: 10.1038/nsmb.2043

Sulimova, G.E., Udina, I.G., Shaikhaev, G.O., et al. (1995). DNA-polymorphism of the Bola-DRB3 gene in cattle due to resistance and susceptibility to leukemia. Genetics, 9, 1294-1299.

Torikai, H., Reik, A., Liu, P.Q., Zhou, Y., Zhang, L., Maiti, S., et al. (2012). A foundation for universal T-cell based immunotherapy: $\mathrm{T}$ cells engineered to express a CD19-specific chimeric-antigen-receptor and eliminate expression of endogenous TCR. Blood, 119(24), 5697-5705. DOI: 10.1182/blood-2012-01-405365

Van Eijk, M.J.T., Stewart-Haynes, J.A., Lewin, H.A. (1992). Extensive polymorphism of the BoLA DRB3 gene distinguished PCR-RFLP. Animal Genetics, 23, 483. DOI: 10.1111/j.1365-2052.1992.tb00168.x

Xu, A., Van Eijk, V.J.T., Park, Ch. (1993). Polymorphism in BoLA - DRB3 Exon 2 correlates with resistance to persistent lymphocytosis caused by bovine leukemia virus. Journal of Immunology, 151(12), 6977-6985.

Zanotti, M., Poli, G., Ponti, W., Polli, M., Rocchi, M., Bolzani, E., et al. (1996). Association of BoLA class II haplotypes with subclinical progression of bovine leukemia virus infection in Holstein - Friesian cattle. Animal Genetics, 27, 337-342. 